\title{
Incidence of pathogens and field emergence of soybean seeds subjected to harvest delay ${ }^{1}$
}

\author{
Fábio Oliveira Diniz ${ }^{*}$, Múcio Silva Reis ${ }^{3}$, Eduardo Fontes Araújo³, \\ Luiz Antônio dos Santos Dias ${ }^{3}$, Tuneo Sediyama ${ }^{3}$, \\ Camilla Atsumi Zanuncio Sediyama-Bhering ${ }^{3}$
}

\begin{abstract}
This study aimed at evaluating seed health quality, as well as seedling emergence in the field, of eight soybean cultivars (UFV-16, Splendor, Vencedora, Confiança, UFV-18, UFV-TN 105, Garantia, and Celeste) subjected to different harvest periods. To this, seeds were harvested at the growth stages $\mathrm{R} 8, \mathrm{R} 8+15$ days, and $\mathrm{R} 8+30$ days, and then submitted to health test and to the test of seedling emergence in field. Results showed that although seeds harvested at 15 and 30 days after the stage R8 had shown a significant increase of fungi infection, especially by Fusarium spp., Phomopsis spp., and Epicoccum spp., the percent seedling emergence in the field was reduced only to seeds harvested 30 days after the reproductive stage R8. Cultivars have shown differentiated behavior between each other in relation to the percent incidence rate of fungi and seedling emergence in the field; and the seeds least infected by fungi were those allowing the highest percent emergence of seedlings in the field.
\end{abstract}

Index terms: Glycine max, seed health, harvest time.

\section{Incidência de patógenos e emergência em campo de sementes de soja submetidas ao retardamento de colheita}

\begin{abstract}
RESUMO - O presente estudo foi realizado com o objetivo de avaliar a qualidade sanitária das sementes, bem como a emergência de plântulas em campo, de oito cultivares de soja (UFV-16, Splendor, Vencedora, Confiança, UFV-18, UFV-TN 105, Garantia e Celeste) submetidas a três diferentes épocas de colheita. Para isso, as sementes foram colhidas nos estádios reprodutivos R8, R8+15 dias e R8+30 dias, e então submetidas aos testes de sanidade e emergência de plântulas em campo. Os resultados mostraram que apesar das sementes colhidas aos 15 e 30 dias após o estádio R8 terem apresentado um aumento significativo da infecção por fungos, especialmente por Fusarium spp., Phomopsis spp. e Epicoccum spp., o percentual de emergência das plântulas em campo foi reduzido somente para as sementes colhidas aos 30 dias após o estádio reprodutivo R8. As cultivares apresentaram comportamento diferenciado entre si, em relação aos percentuais de incidência por fungos e emergência de plântulas em campo, sendo que as sementes menos infectadas por fungos foram as que proporcionaram maior porcentagem de emergência de plântulas no campo.
\end{abstract}

Termos para indexação: Glycine max, sanidade de sementes, época de colheita.

\section{Introduction}

The range of diseases affecting soybean crop is rather extensive, and those caused by fungi are considered as of major importance; not only by their higher number, but also by the losses caused to the yield and the quality of the seeds.

Once seeds highly colonized by pathogens, and with low vigor and low viability, usually have low germination rate; when some of these seeds germinate they will produce weak and diseased plants that are the carriers of initial inoculum

${ }^{1}$ Submitted on 03/19/2013. Accepted for publication on 09/03/2013.

${ }^{2}$ Instituto Federal de Educação, Ciência e Tecnologia do Piauí - IFPI, 64860-000 - Uruçuí, PI, Brasil. for the spread of such pathogens. The problem is exacerbated when the infected seeds do not show any external symptoms, thus being a risk for spreading disease through infected seeds (Krzyzanowski et al., 2008); once these seeds cannot be eliminated during processing, unless they are displaying deformities and/or with their specific mass reduced and which enable their elimination when passing through the density separator and by the gravity table (Dhingra and Acuña, 1997). Moreover, most of the economically important diseases occurring on the soybean crop is caused by seedborn

${ }^{3}$ Departamento de Fitotecnia, Universidade Federal de Viçosa - UFV, 36570-000 - Viçosa, MG, Brasil.

*Corresponding author <fabio.diniz@ifpi.edu.br $>$ 
pathogens (Henneberg et al., 2012). Therefore, in production systems of high quality seeds, the use of the health test is essential on determining the seed health condition of a given sample; and consequently the seed quality of the whole lot.

The soybean seed reaches its maximum dry mass accumulation and its maximum physiological quality at R7 stage (physiological maturation), when it should be harvested. However, due to the high moisture content present in the seeds at this stage, the recommended harvesting point is the R8 stage, when $95 \%$ of pods have the typical coloration of ripe pod, although the seed moisture remains high. Nevertheless, by several factors it is not always possible to harvest the seeds at the most proper time, and thereby delaying the harvest is a need.

When the harvest delay occurs under high temperature, as well as under high relative humidity conditions the amount of seeds infected by pathogenic microorganisms rapidly increases and infection of the seeds generally occurs after onset of pod maturation; although such infection might occur while the pods are still immature (Dhingra and Acuña, 1997). In this regard, some studies have already shown that there is an increase in the ratio of seeds infected by fungi when seeds remain in the field after the reproductive stage R8 (Braccini et al., 2003; Dias et al., 2005).

Soybean seeds subjected to high temperature and high $\mathrm{RH}$ throughout the maturation stage until harvest are exposed to an increased fungi incidence, especially from the genera Fusarium spp. and Phomopsis spp., which are considered the main responsible for reduction on percent germination of the freshly-harvested seeds when these are assessed by the health test in the laboratory (França-Neto and Henning, 1992). In a study carried out on the effect of fungicide application and of harvest time on soybean seeds, Barros et al. (2005) have observed a significant increase on fungi incidence, as well on reduction of percent germination of the seeds subjected to harvest delay. Therefore, when the seeds have high rates of infection, the germination test should be conducted in sand substrate; or else these seeds should be evaluated by seedling emergence test under field conditions.

It is possible that the extent of the percent infection by fungi and the percent germination of soybean seeds harvested after the recommended maturation stage is also influenced by the genotypes used. Furthermore, it is assumed that the field emergence test performed with the seeds harvested under such circumstances is more adequate than the germination test carried out under laboratory conditions. Therefore, the objective of this study was to evaluate the health quality of the seeds, as well as the emergence of the seedlings in field of eight different soybean cultivars harvested at three different harvesting periods.

\section{Materials and Methods}

The study was carried out at the Soybean Breeding Laboratory and at the Seed Research Laboratory of Department of Plant Science, Federal University of Viçosa (UFV), headquartered at Viçosa municipality, state of Minas Gerais. To this, seeds of eight soybean cultivar (UFV-16, Splendor, Vencedora, Confiança, UFV-18, UFV-TN 150, Garantia, and Celeste) were produced at the Experimental Field Professor Diogo Alves de Mello during the 2007/08 crop season. Harvesting was performed at three different harvest periods: reproductive R8 stage (when 95\% of pods have the typical coloration of mature pods), and 15 days and 30 days after this maturation stage.

The experimental design used was a randomized block design, with four replications and with treatments arranged in a split-plot model, where the plots were represented by the eight cultivars, and the subplots represented by the three harvest dates. Each plot was consisted by eight $5 \mathrm{~m}$ long rows, with $0.5 \mathrm{~m}$ interspaces between each other, and with the subplots formed by two of those rows; and discarding the two side rows (plot's border rows).

Climatic conditions were monitored throughout the harvest period (from March 31 to May 28, 2008), and the meteorological data were provided by the Sector of Meteorology of the Department of Agricultural Engineering, Federal University of Viçosa.

Plants were hand harvested when the seeds were still presenting the moisture content between $14 \%$ and $20 \%$, which was determined by the oven method at $105 \pm 3{ }^{\circ} \mathrm{C}$, for $24 \mathrm{~h}$ (Brasil, 2009). After harvesting, the plants with the pods were dried under shade, and when the seeds had moisture content of about $12 \%$, the plants were threshed in a stationary thresher, and the seeds were then subjected to cleaning and sorted through circular screens with mesh diameter of $4.76 \mathrm{~mm}$ and $5.16 \mathrm{~mm}$, to obtain a higher number of seeds. Afterwards, seeds were packed into cotton bags and kept under laboratory environmental conditions; and after this period the seeds were subjected to the health test, and subsequently to the seedling field emergence test.

Health test: for evaluating health quality of seeds the blotter test was used (Goulart, 2004; Henning, 2005). To that, four subsamples of 25 seeds each, to each treatment and replication were previously treated with $70 \%$ ethanol, for $1 \mathrm{~min}$., and with $2 \%$ sodium hypochlorite, during the same period, and then washed with distilled-sterile water. Immediately after, seeds were placed into transparent plastic boxes (Gerbox ${ }^{\circledR}$ type), which had been washed and disinfected with $2 \%$ sodium hypochlorite, containing from six to eight previously autoclaved filter paper sheets moistened with distilled-sterile water and treated with streptomycin. The boxes containing seeds were then incubated 
under laboratory environmental conditions, at approximately $25{ }^{\circ} \mathrm{C}$, for seven days. After such incubation period, the fungi that developed hyphae or reproductive structures on the seeds, and which are characteristic to each fungus species were identified with the aid of stereomicroscope.

Seedling field emergence test: this test was carried out with two subsamples of 50 seeds each, to each treatment and replication, which were sown into $1.0 \mathrm{~m}$ long furrows at a depth of about $3.0 \mathrm{~cm}$, and with $0.5 \mathrm{~m}$ interspaces between the furrows. The percent emergence of seedling was computed with the values obtained by the counting of the numbers of seedling with the first pair of leaflets fully developed, what occurred at the thirteenth day after sowing to all cultivars.

Prior to ANOVA computation, all data obtained in the experiments were subjected to normality tests (Lillifors test) and homogeneity of residual variances between treatments (Cochran test). Means were compared by Tukey test ( $\mathrm{p}<$ $0.05)$; and except to mean data on percent emergence, mean data obtained to fungi incidence percent were transformed to $\arcsin \sqrt{x / 100}$ to perform ANOVA.

\section{Results and Discussion}

Throughout the harvest period the relative humidity has remained between $70 \%$ and $92 \%$, and the average temperature has ranged between 15.5 and $23.1^{\circ} \mathrm{C}$; but rainfalls occurred in small volumes only in the last 25 harvesting days; however, the highest rainfall volume that occurred during such period was $11.6 \mathrm{~mm}$.

The seeds of all cultivars assessed were infected by several pathogenic fungi genera such as: Fusarium spp., Phomopsis spp., Epicoccum spp., Cercospora kikuchii, Colletrichum trucatum, Chaetomium spp., and Alternaria spp.; however, the three first fungi cited have occurred with higher frequency.

On Table 1 is presented a summary of the ANOVA computed with mean data obtained for total percent fungi incidence (TPF), frequency of Fusarium spp (FF), Phomopsis spp. (FP), and Epicoccum spp. (FE), as well as the field emergence (E) of seeds of the soybean cultivars harvested in the three different harvest times studied (stage R8, R8 +15 days, and $\mathrm{R} 8+30$ days). As it can be verified there has been a statistically significant effect of cultivars at levels of $1 \%$ and $5 \%$ probability of $\mathrm{F}$ test to all variables; except for frequency of Fusarium spp., which was not significantly influenced by the two sources of variation. The effect of harvesting time was statistically significant $(\mathrm{p}<0.01)$ for the overall incidence of fungi, frequency of Phomopsis spp., and for seedling emergence in the field. It should also be stressed the lack of significant interaction of cultivar $\mathrm{x}$ harvesting time to all characteristics evaluated.

Table 1. Summary of analysis of variance of data obtained for the total percent incidence of fungi (TIF), frequency of the fungi Fusarium spp (FF), Phomopsis spp. (FP), and Epicoccum spp (FE), and seedling emergence in field (E), of seeds of eight soybean cultivars harvested at different harvesting times (stage R8, R8 +15 days, and $\mathrm{R} 8+30$ days).

\begin{tabular}{crccccc}
\hline \multirow{2}{*}{ Source of variation } & \multirow{2}{*}{ DF } & \multicolumn{5}{c}{ Mean Square } \\
\cline { 5 - 8 } & & TIF & FF & FP & FE & E \\
\hline Bloc & 3 & 226.3966 & 315.0911 & 725.5182 & 248.8121 & 150.2638 \\
Cultivar (C) & 7 & $1102.3062^{* *}$ & 364.6095 & $678.1628^{*}$ & $351.0640^{*}$ & $524.2321^{* *}$ \\
Residue (a) & 21 & 61.0844 & 192.2916 & 189.5898 & 105.7455 & 132.1686 \\
Harvest time (E) & 2 & $1677.2303^{* *}$ & 413.2684 & $1387.8517^{* *}$ & 23.8101 & $2147.5417^{* *}$ \\
E x C & 14 & 31.7004 & 99.5027 & 101.0087 & 82.8843 & 38.7321 \\
Residue (b) & 48 & 37.9579 & 145.1384 & 129.5804 & 91.0270 & 28.3888 \\
\hline CV a (\%) & & 23.0 & 34.2 & 40.4 & 57.2 & 14.6 \\
CV b (\%) & & 18.2 & 29.7 & 33.4 & 53.1 & 6.8 \\
\hline
\end{tabular}

**Significant at $5 \%$ probability level by $\mathrm{F}$ test; * Significant at $1 \%$ probability level by $\mathrm{F}$ test; $\mathrm{DF}=$ degrees of freedom; $\mathrm{CV}=\mathrm{coefficient}$ of variation

There has been an increase in the number of seeds infected by fungi insofar as harvest was delayed, i.e., a delay of 15 days in the harvesting time after reproductive stage $\mathrm{R} 8$ has caused a marked increase on the incidence of pathogenic fungi in the seeds, which was exacerbated when the seeds were harvested at 30 days after the ideal harvesting time to all the eight soybean cultivars studied (Table 2). The overall mean of fungi incidence in the seeds was $54.8 \%$, and despite all cultivars have shown a trend to increased infection levels with the delaying in the harvest time, some of those cultivars have shown lower values than the other cultivars; as for example the cultivars UFV-18, Celeste, and UFV TN-105, which have late or semi-late cycle, have shown $33.7 \%, 34.8 \%$, and $49.6 \%$, respectively of infection by fungi (Table 2). This behavior can be explained by the fact that harvesting of longer cycle cultivars does not coincide with the period of highest rainfall occurrence, which implies in a 
lower fungi incidence in the seeds; while the early and midcycle cultivars may have higher infection levels, as they are subjected to high temperatures and high relative humidity at the end of their cropping cycles (Hamawaki et al., 2002).

Table 2. Mean percent values obtained for the overall incidence of fungi on seeds from eight soybean cultivars harvested at two harvest times after the maturation stage R8.

\begin{tabular}{ccccc}
\hline \multirow{2}{*}{ Cultivar } & \multicolumn{4}{c}{ Harvesting time/ incidence (\%) } \\
\cline { 2 - 4 } & Stage R8 & Stage R8+15 days & Mean* \\
\hline UFV-16 & 63.6 & 56.6 & 78.2 & $66.1 \mathrm{c}$ \\
Splendor & 51.9 & 61.4 & 72.5 & $61.9 \mathrm{bc}$ \\
Vencedora & 56.6 & 57.4 & 73.2 & $62.4 \mathrm{bc}$ \\
Confiança & 63.4 & 67.2 & 81.1 & $70.5 \mathrm{c}$ \\
UFV-18 & 18.6 & 34.6 & 47.8 & $33.7 \mathrm{a}$ \\
UFV-TN 105 & 37.8 & 46.6 & 64.4 & $49.6 \mathrm{ab}$ \\
Garantia & 49.4 & 60.6 & 69.0 & $59.7 \mathrm{bc}$ \\
Celeste & 29.2 & 33.1 & 42.0 & $34.8 \mathrm{a}$ \\
\hline Mean* & $46.3 \mathrm{~A}$ & $52.2 \mathrm{~B}$ & $66.0 \mathrm{C}$ & 54.8 \\
\hline
\end{tabular}

*Means followed by the same lowercase letter in the column and uppercase letter on the line do not significantly differ between each other by Tukey test ( $\mathrm{p}<$ $0.05)$. Values transformed to arcsine $\sqrt{x / 100}$ for ANOVA.

Differentiated behavior of soybean cultivars as to fungal incidence, as well as to their increase on seeds after the reproductive stage $\mathrm{R} 8$ were also found by Braccini et al. (2000). However, Minuzzi et al. (2010) have verified that as the harvest time was increased from the $\mathrm{R} 7$ reproductive stage, the percent fungal incidence has also linearly increased to all the soybean cultivars assessed, and that fungi Aspergillus spp., Fusarium spp., Phomopsis spp., and Cercospora kikuchii were the most frequent in the seeds.

Regarding to incidence of Fusarium spp., the high percent incidence of this fungus was similar in the seeds of all cultivars, with no distinction among harvest times, i.e., there was no significant effect of cultivar and harvest time on incidence of this fungus in seeds (Table 3). Despite many researchers consider this fungus as a saprophyte or as a weak parasite; to Henning (2005), this fungus is included among the fungi pathogenic to soybean seeds, for causing germination problems similar to those caused by the fungus Phomopsis spp. in the tests performed in laboratory. Thus, corroborating what has already been published by Dhingra and Acuña (1997), where the authors claim that Phomopsis spp. and Fusarium spp. are the two most damaging fungi to the soybean seed production under the climatic conditions of Brazil.

Table 3. Mean percentage values obtained for incidence of Fusarium spp., in seeds of eight soybean cultivars harvested at two harvest times after the maturation stage R8.

\begin{tabular}{ccccc}
\hline \multirow{2}{*}{ Cultivar } & \multicolumn{3}{c}{ Harvest time/ incidence (\%) } & \multirow{2}{*}{ Mean* } \\
\cline { 2 - 4 } & Stage R8 & Stage R8 +15 days & Stage R8+30 days & $58.3 \mathrm{a}$ \\
UFV-16 & $60.9^{* *}$ & 68.9 & 45.2 & $66.8 \mathrm{a}$ \\
Splendor & 68.9 & 73.6 & 57.9 & $66.0 \mathrm{a}$ \\
Vencedora & 62.6 & 71.2 & 64.3 & $68.4 \mathrm{a}$ \\
Confiança & 70.4 & 68.1 & 66.7 & $68.1 \mathrm{a}$ \\
UFV-18 & 67.1 & 67.0 & 70.1 & $72.4 \mathrm{a}$ \\
UFV-TN 105 & 78.5 & 72.8 & 65.8 & $48.5 \mathrm{a}$ \\
Garantia & 43.1 & 53.5 & 59.0 & $68.1 \mathrm{a}$ \\
Celeste & 80.6 & 69.9 & $59.1 \mathrm{~A}$ & 64.6 \\
\hline Mean* & $66.5 \mathrm{~A}$ & $68.1 \mathrm{~A}$ & & 6 \\
\hline
\end{tabular}

*Means followed by the same lowercase letter in the column and uppercase letter on the line do not significantly differ between each other by Tukey test ( $\mathrm{p}<$ $0.05)$. ** Values transformed to arcsine $\sqrt{x / 100}$ for ANOVA.

It was also verified that when the harvest was carried out 30 days after stage $\mathrm{R} 8$ there was a statistically significant increase in the number of seeds infected by Phomopsis spp. (Table 4); differently from what was observed for the 
seeds harvested at 15 days after the R8 stage (Table 2) in which the 15-day delay in harvest time was sufficient to significantly increase the number of seeds infected by fungi. Nevertheless, among the different cultivars there was statistically significant difference only between the UFV-18 and Garantia cultivars. A general way, the soybean cultivars can be sorted according to the levels of infection, and the UFV-18 (40.8\%) and Garantia (72.5\%) cultivars represent the extreme values and the other cultivars represent the intermediate values of infection. Hence, the cultivar UFV18 deserves emphasis since it repeats the same behavior presented for the overall fungi incidence in the seeds.

Table 4. Mean percent values obtained to the incidence of the fungus Phomopsis spp. in seeds of eight soybean cultivars harvested in two harvest times after the R8 maturation stage.

\begin{tabular}{ccccc}
\hline \multirow{2}{*}{ Cultivar } & \multicolumn{4}{c}{ Harvest time/Incidence (\%) } \\
\cline { 2 - 4 } & Stage R8 & Stage R8+15 days & Stage R8 + 30 days \\
\hline UFV-16 & $65.9^{* *}$ & 62.0 & 76.2 & $68.0 \mathrm{ab}$ \\
Splendor & 46.4 & 38.3 & 61.6 & $48.8 \mathrm{ab}$ \\
Vencedora & 52.7 & 41.6 & 56.2 & $50.2 \mathrm{ab}$ \\
Confiança & 46.4 & 61.3 & 69.1 & $59.0 \mathrm{ab}$ \\
UFV-18 & 25.4 & 46.3 & 50.6 & $40.8 \mathrm{a}$ \\
UFV-TN 105 & 46.0 & 52.7 & 63.3 & $54.0 \mathrm{ab}$ \\
Garantia & 72.9 & 66.0 & 78.8 & $72.5 \mathrm{~b}$ \\
Celeste & 38.7 & 36.1 & 72.5 & $49.1 \mathrm{ab}$ \\
\hline Mean* & $49.3 \mathrm{~A}$ & $50.5 \mathrm{~A}$ & $66.0 \mathrm{~B}$ & 55.3 \\
\hline
\end{tabular}

*Means followed by the same lowercase letter in the column and uppercase letter on the line do not statistically differ between each other by Tukey test ( $\mathrm{p}<0.05$ ).

** Values transformed to $\arcsin \sqrt{x / 100}$ for ANOVA.

According to Henning (2005) Phomopsis spp. compromises the results of the germination test in the laboratory, and is responsible for reducing percent seed germination. Therefore, it has been the cause of the failure of many seed lots intended to planting, even those containing seeds with high physical and genetic purity levels. This occurs because in the germination process into paper roll there is no constant contact between the infected seed coat and the embryo axis and cotyledons, which does not occur when the germination test is conducted in soil or sand, once the infected seed coats are left on the substrate during emergence. In this sense, França-Neto and Henning (1992) developed a more efficient diagnosis to assess soybean seed quality that surpasses the deleterious effects of fungi restricted to the seed coat and prevents the rejection of seed lots with good quality seeds.

The harvest time had no influence on incidence of Epicoccum spp., which is contrary to what was verified in relation to cultivars, where they have had a differentiated behavior (Table 5). As observed for the incidence of Phomopsis spp., cultivars can be sorted according to seed infection levels, with emphasis on the UFV-16 cultivar, which has had the lowest value for incidence (14.4\%) differing only from the cultivars Splendor and Celeste, both with $40.2 \%$ incidence; whereas the other cultivars showed intermediate values.

Table 5. Mean percent values obtained to the incidence of the fungus Epicoccum spp. in seeds of eight soybean cultivars harvested in two harvest times after the R8 maturation stage.

\begin{tabular}{ccccc}
\hline \multirow{2}{*}{ Cultivar } & \multicolumn{3}{c}{ Harvest time/Incidence (\%) } & \multirow{2}{*}{ Mean* } \\
\cline { 2 - 4 } & Stage R8 & Stage R8 +15 days & Stage R8 + 30 days & $14.4 \mathrm{a}$ \\
UFV-16 & $16.6^{* *}$ & 5.5 & 21.0 & $40.2 \mathrm{~b}$ \\
Splendor & 34.9 & 40.4 & 45.3 & $26.2 \mathrm{ab}$ \\
Vencedora & 32.1 & 21.6 & 24.9 & $31.0 \mathrm{ab}$ \\
Confiança & 40.4 & 29.9 & 22.5 & $36.8 \mathrm{ab}$ \\
UFV-18 & 27.1 & 45.9 & 37.4 & $33.7 \mathrm{ab}$ \\
UFV-TN 105 & 36.3 & 32.4 & 32.4 & $23.2 \mathrm{ab}$ \\
Garantia & 19.9 & 32.1 & 17.6 & $40.2 \mathrm{~b}$ \\
Celeste & 40.0 & 47.7 & $29.6 \mathrm{~A}$ & 30.7 \\
\hline Mean* & $30.9 \mathrm{~A}$ & $31.9 \mathrm{~A}$ & & 2.6 \\
\hline
\end{tabular}

*Means followed by the same lowercase in the column and uppercase letter on the line do not statistically differ between each other by Tukey test ( $\mathrm{p}<0.05)$. $* *$ Values transformed to $\arcsin \sqrt{x / 100}$ for ANOVA. 
In assessing health quality of soybean seeds, the fungus Epicoccum spp. has not been listed among the most frequent pathogens (Costa et al., 2003; Gomes et al., 2009; Minuzzi et al., 2010). It is possible that in studies on seed pathology its low incidence or the lack on its detection in soybean seeds is due to the possibility of this fungus to be mistaken with other pathogens at the evaluation time by the health test.

In relation to seedling emergence in the field, results have shown that the delay of 30 days in the harvest time, after the R8 stage, has significantly reduced the percentage of emerged seedlings (Table 6). As far as the different cultivars, it was observed that percent values obtained for seedling emergence in the field have had in a stratified format, and at three different levels: one level with the percent emergence above $80 \%$, represented by the cultivars Vencedora, UFV-18, UFV TN-105 and Celeste; another level with the percent emergence of $65 \%$, represented only by the cultivar UFV-16, and the other cultivars have formed an intermediate group with germination percentage ranging between $76 \%$ and $80 \%$ (Table 6 ).

Table 6. Mean of percent values obtained for field emergence of soybean seedlings, originating from seeds of eight cultivars harvested in two harvest times after the R8 maturation stage.

\begin{tabular}{|c|c|c|c|c|}
\hline \multirow{2}{*}{ Cultivar } & \multicolumn{3}{|c|}{ Harvest time/Emergence (\%) } & \multirow{2}{*}{ Mean* } \\
\hline & Stage R8 & Stage $R 8+15$ days & Stage $R 8+30$ days & \\
\hline UFV-16 & 75 & 72 & 49 & $65 \mathrm{~b}$ \\
\hline Splendor & 83 & 79 & 69 & $77 \mathrm{ab}$ \\
\hline Vencedora & 88 & 88 & 76 & $84 \mathrm{a}$ \\
\hline Confiança & 82 & 78 & 67 & $76 \mathrm{ab}$ \\
\hline UFV-18 & 89 & 89 & 71 & $83 \mathrm{a}$ \\
\hline UFV-TN 105 & 90 & 88 & 75 & $84 \mathrm{a}$ \\
\hline Garantia & 86 & 80 & 71 & $79 \mathrm{ab}$ \\
\hline Celeste & 87 & 87 & 79 & $84 \mathrm{a}$ \\
\hline Mean* & $85 \mathrm{~A}$ & $82 \mathrm{~A}$ & $70 \mathrm{~B}$ & 79 \\
\hline
\end{tabular}

*Means followed by the same lowercase letter in the column and uppercase letter on the line do not statistically differ between each other by Tukey test $(\mathrm{p}<0.05)$.

Despite working with a single cultivar Pelúzio et al. (2008) concluded that the delay in harvest resulted in decrease in germination and vigor of soybean seeds. However Santos et al. (2005) in studies with different soybean genotypes have found that seed harvested at the physiological maturity showed no difference in the percent of seedling emergence in the field. Nevertheless, when subjected to a harvest delay from 15 to 30 days after the R8 stage different behaviors occurred among cultivars. Thus, the delay on harvesting is capable of signaling those genotypes that exhibit better seed quality or to better tolerate deterioration conditions imposed by delayed harvest (Lima et al., 2007).

Despite the delay on harvest for 15 days after the $\mathrm{R} 8$ stage have led to the increased percentage of the seedlings infected by fungi, that same period was not sufficient to cause reduction in the percentage of seedling emergence in the field, which occurred only after 30 days precisely when there was a higher incidence of fungi in the seeds. Albrecht et al. (2008) found that the highest fungi incidence may have been the cause of problems in the performance of the soybean seeds in terms of physiological quality. However, Henning et al. (2011) found a high incidence of fungi in corn seeds; however, without compromise physiological quality of the seeds harvested at physiological maturity point. Thus, the increased incidence of fungi in the seeds do not necessarily implies on reduction of seedling emergence in the field. Evidently, the damage level caused to seedling emergence is also dependent on the genera of the fungi detected with higher frequency, once the seed germination in sand or soil is less affected by fungi, especially those confined to the seed coat.

The reduction in the seedling emergence percentage can not be attributed only to the effect of the fungi infection, but also to the reduction of the physiological quality of the seeds, caused for the harvest delay. The emergence in the field was little affected by the seeds infection, since the reduction of the emergence percentage occurred only in the seeds with higher infection level, harvested 30 days after the R8 stadium.

\section{Conclusions}

Soybean seeds harvested at 15 or 30 days after the reproductive stage R8 show significant increase on infection by fungi, especially from genera Fusarium spp., Phomopsis spp., and Epicoccum spp.

The percentage of seedling emergence under field conditions is negatively affected when the seeds used in the 
sowing were harvested 30 days after reproductive stage $\mathrm{R} 8$.

The soybean cultivars had different performance in relation to fungi incidence and seedling emergence in the field; the cultivars less infected by fungi had the highest seedling emergence percentage.

\section{References}

ALBRECHT, L.P.; BRACCINI, A.L.; SCAPIM, C.A.; AGUIAR, C.G.; ÁVILA, M.R.; STULP, M. Qualidade fisiológica e sanitária das sementes sob semeadura antecipada da soja. Scientia Agraria, v.9, n.4, p.445-454, 2008. http://ojs.c3sl.ufpr.br/ojs2/index.php/agraria/article/view/12476

BARROS, H.B.; SEDIYAMA, T., REIS, M.S.; CECON, P.R. Efeito da aplicação de fungicidas e da época de colheita na qualidade sanitária de sementes de soja. Acta Scientiarum Agronomy, v.27, n.4, p.639-644, 2005. http://www.redalyc.org/articulo.oa?id=187117008011

BRACCINI, A.L.; ALBRECHT, L.P.; ÁVILA, M.R.; SCAPIM, C.A.; BIO, F.E.I.; SCHUAB, S.R.P. Qualidade fisiológica e sanitária das sementes de quinze cultivares de soja (Glycine max (L.) Merrill) colhidas na época normal e após o retardamento da colheita. Acta Scientiarum Agronomy, v.25, n.2, p.449-457, 2003. http://periodicos.uem.br/ojs/index.php/ActaSciAgron/article/view/2153

BRACCINI, A.L.; REIS, M.S.; BRACCINI, M.C.L.; SCAPIM, C.A.; MOTTA, I.S. Germinação e sanidade de sementes de soja (Glycine max (L.) Merrill) colhidas em diferentes épocas. Acta Scientiarum Agronomy, v.22, n.4, p.1017-1022, 2000. http://periodicos.uem.br/ojs/index.php/ ActaSciAgron/article/view/2868/2047

BRASIL. Ministério da Agricultura, Pecuária e Abastecimento. Regras para análise de sementes. Ministério da Agricultura, Pecuária e Abastecimento. Secretaria de Defesa Agropecuária. Brasília, DF: MAPA/ACS, 2009. 395p. http://www.agricultura.gov.br/portal/page/portal/Internet-MAPA/paginainicial/vegetal/sementes-mudas

COSTA, N.P.; MESQUITA, C.M.; MAURINA, M.C.; FRANÇA-NETO, J.B.; KRZYZANOWSKI, F.C.; HENNING, A.A. Qualidade fisiológica, física e sanitária de sementes de soja produzidas no Brasil. Revista Brasileira de Sementes, v.25, n.1, p.128-132, 2003. http://www.scielo.br/pdf/rbs/v25n1/19641.pdf

DIAS, A.C.P.; REIS, M.S.; SEDIYAMA, C.S.; MOREIRA, M.A.; ROCHA, V.S. Qualidade fisiológica de sementes de soja (Glycine max (L.) Merrill) sem lipoxigenases. Revista Ceres, v.52, n.301, p.453-466, 2005. http://www. ceres.ufv.br/ceres/revistas/V52N301P03905.pdf

DHINGRA, O.D.; ACUÑA, R.S. Patologia de sementes de soja. Viçosa: UFV, 1997. 119p.

FRANÇA-NETO, J.B.; HENNING, A.A. DIACOM: diagnóstico completo da qualidade da semente de soja. Londrina: EMBRAPA-CNPSo, 1992. 22 p. (EMBRAPA CNPSo. Circular Técnica, 10).
GOMES, D.P.; KRONKA, A.Z.; BARROZO, L.M.; SILVA, R.P.; SOUZA, A.L.; SILVA, B.M.S.; PANIZZI, R.C. Efeito da colhedora, velocidade e ponto de coleta na contaminação de sementes de soja por fungos. Revista Brasileira de Sementes, v.31, n.3, p.160-166, 2009. http://www.scielo.br/pdf/ $\mathrm{rbs} / \mathrm{v} 31 \mathrm{n} 3 / \mathrm{a} 18 \mathrm{v} 31 \mathrm{n} 3 . \mathrm{pdf}$

GOULART, A.C.P. Fungos em sementes de soja: deteç̧ão, importância e controle. Dourados: Embrapa Agropecuária Oeste, 2004. 72p.

HAMAWAKI, O.; TJULIATTI, F.C.; GOMES, G.M.; RODRIGUES, F.A.; SANTOS, V.L.M. Avaliação da qualidade fisiológica e sanitária de sementes de genótipos de soja do ciclo precoce/médio em Uberlândia, Minas Gerais. Fitopatologia Brasileira, v.27, n.2, p.201-205, 2002. http://www.scielo.br/ $\mathrm{pdf} / \mathrm{fb} / \mathrm{v} 27 \mathrm{n} 2 / 9145 . \mathrm{pdf}$

HENNEBERG, L.; JACCOUD FILHO, D.S.; RAURO, L.; PANOBIANCO, M. Efficiency of methods to detect Sclerotinia sclerotiorum in commercial soybean seed lots. Revista Brasileira de Sementes, v.34, n.1, p.061-069, 2012. http://www.scielo.br/pdf/rbs/v34n1/a08v34n1.pdf

HENNING, A.A. Patologia e tratamento de sementes: noções gerais. 2.ed. Londrina: Embrapa Soja, 2005. 52p. (Embrapa Soja. Documentos, 264).

HENNING, F.A.; JÚNIO, E.A.J.; MERTZ, L.M.; PESKE, S.T. Qualidade sanitária de sementes de milho em diferentes estádios de maturação. Revista Brasileira de Sementes, v.33, n.2, p.316-321, 2011. http://www.scielo.br/pdf/ $\mathrm{rbs} / \mathrm{v} 33 \mathrm{n} 2 / 14 . \mathrm{pdf}$

KRZYZANOWSKI, F.C.; FRANÇA-NETO, J.B.; HENNING, A.A.; COSTA, N.P. A semente de soja como tecnologia e base para altas produtividades Série Sementes. Londrina: Embrapa Soja, 2008. 8p. (Embrapa Soja. Circular Técnica, 55).

LIMA, W.A.A.; BORÉM, A.; DIAS, D.C.F.S.; MOREIRA, M.A.; DIAS, L.A.S.; PIOVESAN, N.D. Retardamento de colheita como método de diferenciação de genótipos de soja para qualidade de sementes. Revista Brasileira de Sementes, v.29, n.1, p.186-192, 2007. http://www.scielo.br/pdf/rbs/v29n1/26.pdf

MINUZZI, A.; BRACCINI, A.L.; RANGEL, M.A.S.; SCAPIM, C.A.; BARBOSA, M.C.; ALBRECHT, L.P. Qualidade de sementes de quatro cultivares de soja, colhidas em dois locais no estado do Mato Grosso do Sul. Revista Brasileira de Sementes, v.32, n.1, p.176-185, 2010. http://www. scielo.br/pdf/rbs/v32n1/v32n1a20.pdf

PELÚZIO, J.M.; RAMO, L.M.; FIDELIS, R.R.; AFFÉRRI, F.S.; CASTRO NETO, M.D.; CORREIA, M.A.R. Influência da dessecação química e retardamento de colheita na qualidade fisiológica de sementes de soja no sul do estado do Tocantins. Bioscience Journal, v.24, n.2, p.77-82, 2008. http:// www.seer.ufu.br/index.php/biosciencejournal/article/view/6996/4637

SANTOS, M.R.; REIS, M.S.; SEDIYAMA, T.; SEDIYAMA, C.S.; DIAS, L.A.S.; ARAÚJO, E.F. Qualidade fisiológica e sanitária de sementes de soja submetidas a diferentes épocas de colheita e correlações com a emergência de plântulas no campo. Revista Ceres, v.52, n.302, p.535-554, 2005. http://www. ceres.ufv.br/ceres/revistas/V52N302P04705.pdf 